\title{
Penal Protection for Electronic Consumer
}

\author{
Dr. Bassam Mostafa Tubishat* \\ Faculty of Law, Associate Professor, Irbid National University, Jordan
}

*Corresponding Author: Dr. Bassam Mostafa Tubishat, Faculty of Law, Associate Professor, Irbid National University, Jordan

\begin{abstract}
The emergence of e-commerce and the accompanying technological development has made consumer an easy prey for professional who possess all elements of knowledge and professional at a time when legislations have become incapable to protect consumers as before, the need for legislation is primarily concerned with protecting consumer and granting him legal guarantees to protect him from injustice of traders, the first of these specialized legislation in consumer protection appeared in America and Europe, then spread to our Arab countries, where many of them followed the example of Western countries in the enactment of consumer protection legislation.
\end{abstract}

Keywords: Penal Protection, Electronic Consumer, Electronic Fraud, Electronic Deceit, Electronic Commerce

\section{INTRODUCTION}

There have been many significant developments in information and communication technology in recent years, thus changing nature and lifestyle of all consumers, both in developed and developing countries, these means have become tangible for the conclusion of many transactions through it and creation actions through it, the most important of them is Internet, where transformation from Just data exchange via e-mail to completion of business operations, it imposed itself strongly.

So many consumers and businesses have become more vulnerable to usual forms of fraud and new forms of electronic fraud in the world, the emergence of the Internet and e-commerce has exacerbated the cases and forms of attack on infrastructure, which known as cyber-attack.

Hence, we should seek to identify the potential types and forms of fraud and deceit in business dealings that take place in the context of modern information technology or communications or more precisely what is known as electronic trading fraud.

Hence the need for consumer protection in electronic market has begun; the confidence in electronic market is one of the most important needs of consumer in order to meet his personal needs, since the legal protection of consumer, whether in pre-contract stage, at the stage of electronic contract conclusion, or at the stage of execution of electronic contract is very important because consumer can be a weak party, in such a case, consumer may need a particular commodity, therefore he will be subject to unusual and unfair conditions. Seller is the strong party in this contract against consumer ${ }^{(1)}$.

Based on above, we divided this study into three topics as follows:

The first topic: the general concept of electronic consumer protection

The second topic: the justification of electronic consumer protection

The third topic: penal protection of consumer against commercial and industrial fraud

The fourth topic: penal protection of consumer against crime of fraud

\section{The First Topic: The General Concept of Electronic Consumer Protection}

The importance of protecting consumer because he is the weak party in contract while professionals are at the center of power in the face of consumers, also because contract in electronic transactions is concluded remotely while product is not at contracting place in consumer hands, due to great risk involved in consuming process at all stages ,to protect consumer from buying goods and services risks and to protect him from becoming a victim, law should protect consumer in electronic transactions to 
extract necessary mechanisms to restore balance in consuming relations, thereby decreasing harm and risk to consumer, it is not at national level only, because electronic transactions are international transactions often, they are conducted through Internet, do not know limits and extend to include all over the world, which calls for unification of international legal system to coordinate between legal centers of contractors and widen scope of legal protection for consumer, hence the importance of consumer and consuming process appears ${ }^{(2)}$.

Therefore, electronic consumer is a person who enters into various electronic contracts like purchase, rent, use, etc. in order to provide all goods and services he needs to satisfy his personal or family needs, without intention of re-marketing and without having technical experience to deal with them.

\subsection{Consumer Concept in E-Commerce}

Egyptian legislator identified consumer in Egyptian consumer protection law in Article (1) that (Everybody to whom a product is submitted to satisfy his personal or family needs or being dealt or contracting with him in this regard) ${ }^{(3)}$.

Jordanian legislator defined consumer in the Jordanian Consumer Law as (the natural or legal person who obtains a good or service in exchange or without payment to satisfy his personal situation or for the needs of others, item or service for resale or lease are notinclude.) ${ }^{(4)}$

We note that the Egyptian legislator has taken the narrow concept of consumer while the definition of Jordanian legislator is ambiguous as the phrase (or for the needs of others) is not clear, it can carry more than meaning. Therefore, it is necessary to rephrase, define and control this text so that it leaves no room for interpretation.

As well as French consuming law issued on July 26, 1993 defined consumers (people who have gotten or have used portables or services for non-professional use).

\section{The Second Topic: The Justification of Electronic Consumer Protection}

It is summarized of consumer's lack of technical information and technical knowledge enlightenment, consumer's need for electronic services in shopping and communication means, in addition the impact of modern development in internet on consumer.

\subsection{Modern Development in the Internet}

In early of 1990s, what is called internet emerged and many techniques and tools emerged that contributed to development of this network ${ }^{(5)}$.

Therefore, the Internet is one of the most advanced technical advance services that depends on the interaction of consumer with computer, and consists of thousands of computers connected to internet, which you can access many goods and services through in an easy way.

The technological development in this aspect is a scientific reality with continuous developments, which should lead to improved trade links between provider and consumer in order to achieve the best performance of e-business practices ${ }^{(6)}$,however, technical development has a negative side that can affect the legal description of an e-commerce contract over internet, previewing the sale in real-way or meeting supplier in traditional contract ${ }^{(7)}$.

\subsection{Consumer Need for Electronic Services:}

The development of internet has led to interest in commercial sites that contain multiple services such as tourist real estate services, knowledge and other important services. The consumer's need for electronic services stems from the fact that they provide high quality products and services at reasonable prices due to large number of commercial websites and the increased competition between these sites to provide the best for consumer, in addition to excellent after-sales services, the importance of e-services on internet is increasing in consumer demand, it is the focus of demand for many consumers, hence the need is to seek protection for consumer in an urgent and clear form ${ }^{(8)}$.

\subsection{Lack of Consumer to Technical Informational Enlightenment}

The network around the world is open to millions of people. E-mail, Web sites and direct interaction, they all come with one goal: to introduce consumer different types of products and services and contracting with him through it ${ }^{(9)}$. 
The ability of consumer to handle computer and internet makes it easier for him to reach products and services he wants, we have to distinguish between so-called consumer information, which is a right of consumer and consumer information knowledge of network, which represents a minimum for consumer's access to computer and internet, in addition to problems that may be face consumer when he goes to depth of network ${ }^{(10)}$, in addition to lack of consumer knowledge in internet that may lead him to tricks and deceiving by internet hackers through fake sites or imaginary contracts ${ }^{(11)}$.

So, consumer's need protection in e-contracting that stems from the fact that consumer is the least experience and knowledge in e-business transactions and the least powerful in economic equation ${ }^{(12)}$.

\section{The Third Topic: Penal Protection of Consumer Against Commercial and INDUSTRIAL FRAUD}

Commercial and industrial fraud can be defined as:(any act that would alter the nature of mental or its usefulness in which action of actor is entered, with no concern to means by which actor has sought to achieve his goal, fraud may be made by adding less valuable mentals instead of original, or reduction some substances or addition other substances to increase quantity and reduce quality, and other images that cannot be limited where cheaters are trained to devise to achieve their purposes by obtaining large and illegal profits ${ }^{(13)}$.

Fraud may be caused by man as in case of addition, decrease or mixing or fraud may be due to reasons beyond control of man, such as putrefaction of product as a result of its nature, such as meat, eggs, cheese and so on.

In all cases, crime of fraud has two pillars, one mental and the other mental, where mental element is achieved by any of the following acts:

- Fraud or fraud attempt, as well as corruption that occurs on products.

- Offering, offering for sale or selling counterfeit or corrupt materials ${ }^{(14)}$.

It should be noted that this mental element is available even in case of electronic sale, by offering or offering for sale through internet corrupt or counterfeit goods that reach consumer later.

The mental element is also achieved in this crime by intention existence of fraud, it means preoccupation of perpetrator will to achieve criminal incident, with knowledge that elements are available in fact ${ }^{(15)}$,in addition, it is difficult to imagine that professional in electronic sales contract does not know the reality of defects in his goods or product, fraud also relates to cases of imitation in industrial production stages, as well as the imitation of misleading trademarks to consumer.

\section{The Fourth Topic: Penal Protection of Consumer Against Crime of Fraud}

A producer or distributor may resort to promoting his products in misleading advertising that may sometimes involve scientific inaccuracies in order to achieve a large amount of profit at expense of consumer who is deceived by such publicity.

For example, dried dairy manufacturers use internet advertising and others to say that their products are full alternative to mother's milk; the world health organization (WHO) proved that millions of children die annually before their first year of age, in third world countries especially, because their feeding depend on dairy products ${ }^{(16)}$.

These incidents and other indicate that fraud crimes can occur via internet, where fraudulent methods representing in misleading propaganda of products benefits and away to capture consumer money ${ }^{(17)}$.

The French Consumer Law of 1993 included provisions that combat fraud and deception, in order to protect consumers, where legal texts include two acts. The first is organized by articles (121) and beyond. It penalizes all those who carry out full propaganda or those they are liable to make mistakes. The second is organized by articles (213) and beyond, which penalizes cheating and deceit.In both, deceiver, perpetrator of fraud or uncensored should be liable to imprisonment, fine or one of these penalties, additional supplementary penalties may be added.

Comparative legislation punishes and criminalizes the act of illegal entry into e-commerce sites and obtains consumer data. It protects the means of electronic payment from infringing, and infringes consumer credit card statements and criminalizes forgery of electronic documents to which the consumer is a party. 


\section{CONCLUSION}

As a result of cybercrime emergence, inability of traditional penal laws to face them, most of world countries, developed countries especially, sought to enact legislation and laws to deal with these crimes.

The United States is one of first countries that tried to remedy problems by issuing legislation in 1984; US Congress issued a law called Information Fraud and other laws.

Of Arab countries that confronted this phenomenon was Sultanate of Oman, it issued Decree No. 72/2001. It included amendments to some provisions of Penal Code, including unlawful capture of information and data, illegal entry into computer systems, espionage and tapping of data and information.

Jordan also issued the Electronic Transactions Law No. 15 in 2015, as well as the Electronic Crimes Law No. (27) In the year 2015 and its amendments, after the traditional legal texts are not able to stand in front of them. We believe that the Arab legislator should intervene more seriously and responsibly to keep pace with developments in the field of consumer protection in developed countries.

\section{REFERENCES}

[1] Osama Ahmed Badr, Consumer Protection in Electronic Contracting, First Edition, University Publishing House, 2005.

[2] OshenHanan, Consumer Protection in E-Contract, Master's Thesis, Faculty of Law, Annaba, 2012,

[3] Bashar Talal Momani - Problems of online contracting - First Edition - the world of modern books Jordan 2004.

[4] Hassan Abdel Basset Al-Ghamiei, Consumer Protection in Egypt compared to the Protection Status in the European Market and the Middle East, First Edition, Egypt, Dar Al-Fikr, 1996.

[5] Khaled Mamdouh, Consumer Protection in E-Commerce Contracts, Khaled MamdouhAliKenana Online.

[6] Samiha Al-Qiloubi, Food Fraud and Consumer Protection, Research for Consumer Protection Conference, Cairo, March 1993.

[7] Tarek Abdel-Aal, E-Commerce, Concepts, Experiences, Challenges, Technological, Financial, Marketing and Legal Dimensions, First Edition, Egypt, University House, 2003.

[8] Abdullah Hussein Mahmoud, Consumer Protection from Commercial or Industrial Fraud, Dar al-Nahda alArabiya, Cairo, 2002.

[9] Abdullah Deeb Abdullah - Consumer Protection in Electronic Contracting (Comparative Study), Master Thesis - An-Najah University - Palestine 2009.

[10] Mohammed ShukriSorour, E-Commerce and Consumer Protection, presented Research to Scientific Conference, Dubai Police Academy, United Arab Emirates, 25-27 February 2003.

[11] Jordanian Consumer Protection Law, March 14, 2013.

\section{MARGINS}

[12] Osama Ahmed Badr, Consumer Protection in Electronic Contracting, First Edition, University Publishing House, 2005, p. 21.

[13] Khalid Mamdouh, Consumer Protection in E-Commerce Contracts, d. Khaled Mamdouh Ali KenanaOnline2010 .

[14] Egyptian Consumer Protection Law No. 76 of 2006.

[15] Jordan Consumer Protection law, March 14, 2013.

[16] Tariq Abdel Aal, E-Commerce - Concepts - Experiences - Challenges - Technological, Financial, Marketing and Legal Dimensions - First Edition, Egypt, University House, 2003, p36.

[17] Bashar Al-Momani, Problems of Online Contracting - First Edition - The World of Modern Books Jordan, 2004, p10.

[18] Osama Ahmed Badr, op. Cit., P. 25.

[19] Abdullah Deeb Abdullah, Consumer Protection in Electronic Contracting (Comparative Study), Master Thesis, An-Najah University, Palestine, 2012, p. 31.

[20] Osama Ahmed Badr, op. Cit., P. 108.

[21] Bashar Talal Momani, op. Cit., P. 
[22] OchanHanan, Consumer Protection in E-Contract, Master Thesis, Faculty of Law, Annaba, 2012, p.

[23] Hassan Abdel-Basset Al-Ghami, Consumer Protection in Egypt compared to Protection in the European Market and the Middle East, First Edition, Egypt, Dar Al-Fikr, 1996, p 13.

[24] Samiha Al-Qiloubi, Food Fraud and Consumer Protection - A Study of the Consumer Protection Conference - Cairo, March 1993, p. 4.

[25] Abdullah Hussein Mahmoud, Consumer Protection from Commercial or Industrial Fraud, Dar al-Nahda alArabiya, Cairo, 2002, p 9.

[26] Abdullah Hussein Mahmoud - ibid. - p. 10 and beyond.

[27] Mohammed ShukriSorour, E-Commerce and Consumer Protection, presented Research to the Scientific Conference, Dubai Police Academy, United Arab Emirates, 25-27 February 2003, p. 176.

[28] (Mohammad Muharram _ fraud\& Electronic Commerce). Presented to the Dubai Police Conference, April 2003, Volume 1, page 493.

\section{AUTHORS' BIOGRAPHY}

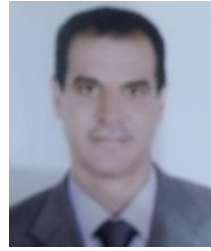

Dr. Bassam Mustafa Tubishat, works at the ir id national university associate professor in the Faculty of Law and the allocation of commercial law branch of industrial and commercial property and studied the students of bachelor and master and his research interests in the field of his specialty. He have overseen many of the Masters letters

Citation: Dr. Bassam Mostafa Tubishat. "Penal Protection for Electronic Consumer". International Journal of Humanities Social Sciences and Education (IJHSSE), vol 6, no. 4, 2019, pp. 1-5 doi: http://dx.doi.org/10.20431/2349-0381.0604001.

Copyright: (C) 2019 Authors. This is an open-access article distributed under the terms of the Creative Commons Attribution License, which permits unrestricted use, distribution, and reproduction in any medium, provided the original author and source are credited. 